\title{
Formal total syntheses of classic natural product target molecules via palladium-catalyzed enantioselective alkylation
}

\author{
Yiyang Liu, Marc Liniger, Ryan M. McFadden, Jenny L. Roizen, Jacquie Malette, \\ Corey M. Reeves, Douglas C. Behenna, Masaki Seto, Jimin Kim, Justin T. Mohr, \\ Scott C. Virgil and Brian M. Stoltz
}

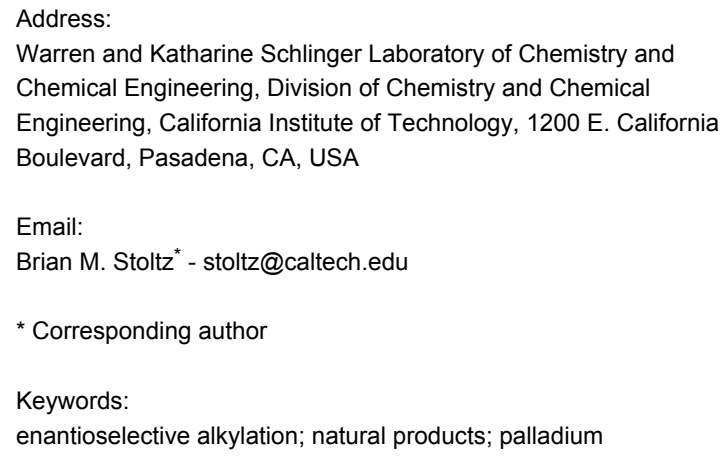

\author{
Beilstein J. Org. Chem. 2014, 10, 2501-2512. \\ doi:10.3762/bjoc. 10.261 \\ Received: 11 August 2014 \\ Accepted: 09 October 2014 \\ Published: 28 October 2014 \\ Associate Editor: S. Bräse \\ (C) 2014 Liu et al; licensee Beilstein-Institut. \\ License and terms: see end of document.
}

\begin{abstract}
Pd-catalyzed enantioselective alkylation in conjunction with further synthetic elaboration enables the formal total syntheses of a number of "classic" natural product target molecules. This publication highlights recent methods for setting quaternary and tetrasubstituted tertiary carbon stereocenters to address the synthetic hurdles encountered over many decades across multiple compound classes spanning carbohydrate derivatives, terpenes, and alkaloids. These enantioselective methods will impact both academic and industrial settings, where the synthesis of stereogenic quaternary carbons is a continuing challenge.
\end{abstract}

\section{Introduction}

Catalytic enantioselective allylic alkylation has emerged as a powerful method for the construction of building blocks bearing quaternary carbon and fully substituted tertiary centers [1,2]. A recent addition developed by our laboratory is the allylic alkylation of nonstabilized enolate precursors to form $\alpha$-quaternary carbonyl compounds (Scheme 1) [3]. Once the key stereocenter is set by this chemistry, further elaboration allows access to many bioactive small molecules. In our lab alone, this palladium-catalyzed alkylation has enabled the enantioselective total syntheses of dichroanone [4], elatol [5], cyanthiwigins [6-8], carissone [9], cassiol [10], chamigrenes [11], and liphagal [12]. Other labs have also utilized our method in natural product total synthesis $[13,14]$. Often, it is the case that a new technology that allows the synthesis of building blocks will open up new avenues to complex structures of long standing interest $[15,16]$. Herein we detail the application of this asymmetric chemistry in formal total syntheses of "classic" natural product targets across a range of compound families by strategic selection of allylic alkylation substrates and subsequent product transformations. 


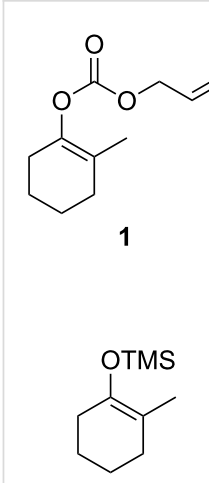

3<smiles>C=CCOC(=O)C1(C)CCCCC1=O</smiles>

4
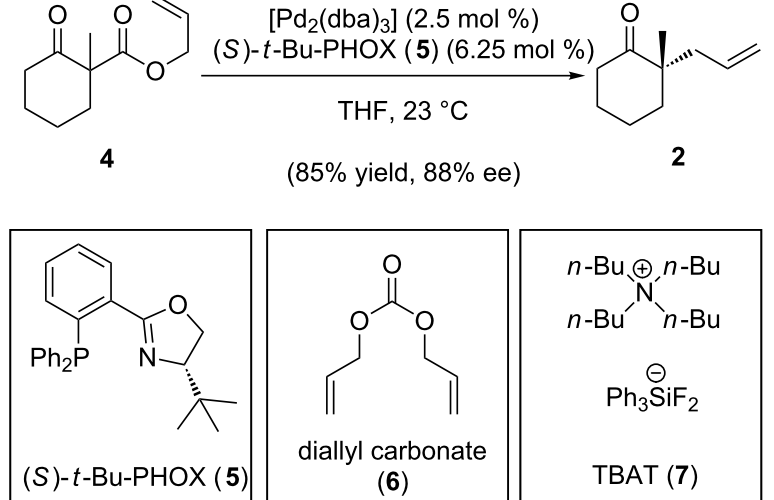

(85\% yield, $88 \%$ ee)

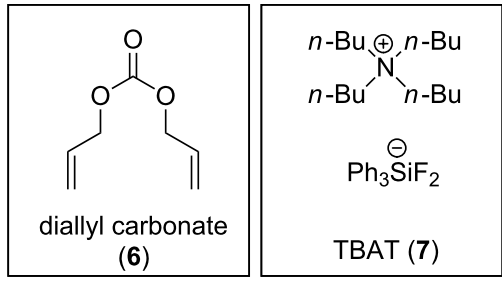

Scheme 1: Three classes of Pd-catalyzed enantioselective allylic alkylations.

\section{Results and Discussion}

\section{A) Thujopsene}

The Japanese hiba tree, Thujopsis dolabrata has been used for centuries as decoration and within traditional architecture [17]. The plant is a member of the order Cupressaceae, and its fragrant wood oil contains numerous sesquiterpenes including mayurone (8) [18,19], widdrol (9) [20], and (-)-thujopsene (10) (Figure 1) [21,22]. The wood oil is a potent dust mite deterrent; thus, in addition to its ornamental value, the hiba tree also provides and environmentally benign means of pest control $[23,24]$.

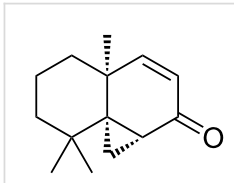

mayurone (8)

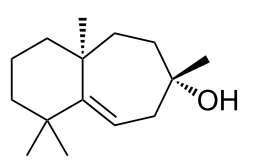

widdrol (9)

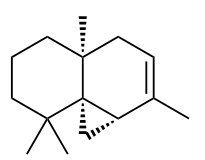

(-)-thujopsene (10)
Figure 1: Selected natural products from Thujopsis dolabrata.

(-)-Thujopsene (10) has attractive features to the synthetic chemist. Its tricyclo[5.4.0.0 $\left.0^{1,3}\right]$ undecane skeleton contains three contiguous all-carbon quaternary centers, two of which are stereogenic. Being a hydrocarbon, (-)-thujopsene (10) has few natural handles for retrosynthetic analysis. Inspired by the complexity of this relatively small natural product, several total syntheses of racemic $\mathbf{1 0}$ have been reported [25-29] along with at least two enantioselective routes [30-32].

One enantiospecific total synthesis of (+)-thujopsene (10) by Srikrishna and Anebouselvy began with $(R)$-carvone (11) (Scheme 2) [33]. During the total synthesis, the authors prepared carboxylic acid $(+)-12$ over a 14-step sequence. We planned to intercept the antipode of $(+)-\mathbf{1 2}$ using the palladiumcatalyzed enantioselective alkylation chemistry described above.<smiles>C=C(C)[C@H]1CC=C(C)C(=O)C1</smiles>

(R)-carvone (11)

13

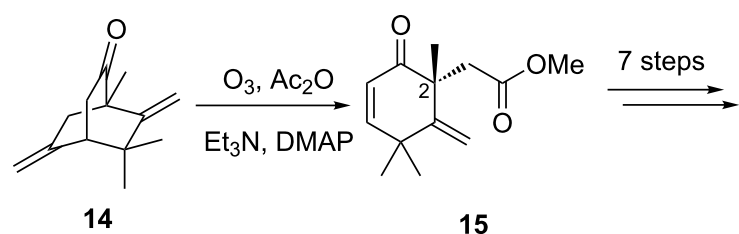

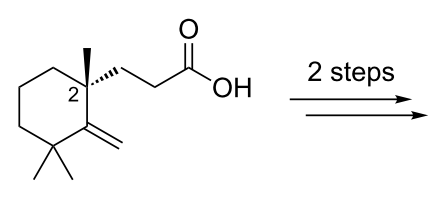

$(+)-12$

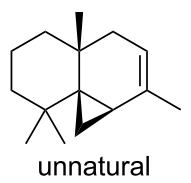

(+)-thujopsene (10)
Scheme 2: Srikrishna and Anebouselvy's approach to (+)-thujopsene.

We commenced a formal total synthesis of (-)-thujopsene (10) with the goal of improved efficiency compared to the Srikrishna/Anebouselvy route and to use enantioselective palladium catalysis to install the initial stereocenters (Scheme 3). Treatment of 16 with LiHMDS in THF, followed by allyl chloroformate, furnished the known carbonate $\mathbf{1 7}$ in high yield [34]. This substrate smoothly undergoes palladium-catalyzed enantioselective decarboxylative allylation in the presence of $(S)-t$-BuPHOX (5), giving allyl ketone (-)-18 in 94\% yield and 91\% ee [34]. Treatment of the ketone (-)-18 with $\mathrm{MeMgBr}$ at $23{ }^{\circ} \mathrm{C}$ provided a mixture of two diastereomeric alcohols 19A and 19B in $94 \%$ yield. Without separation, the diastereomers were rapidly carried through a three-step sequence of hydroboration/ oxidation, terminal alcohol silylation, and tertiary alcohol dehy- 


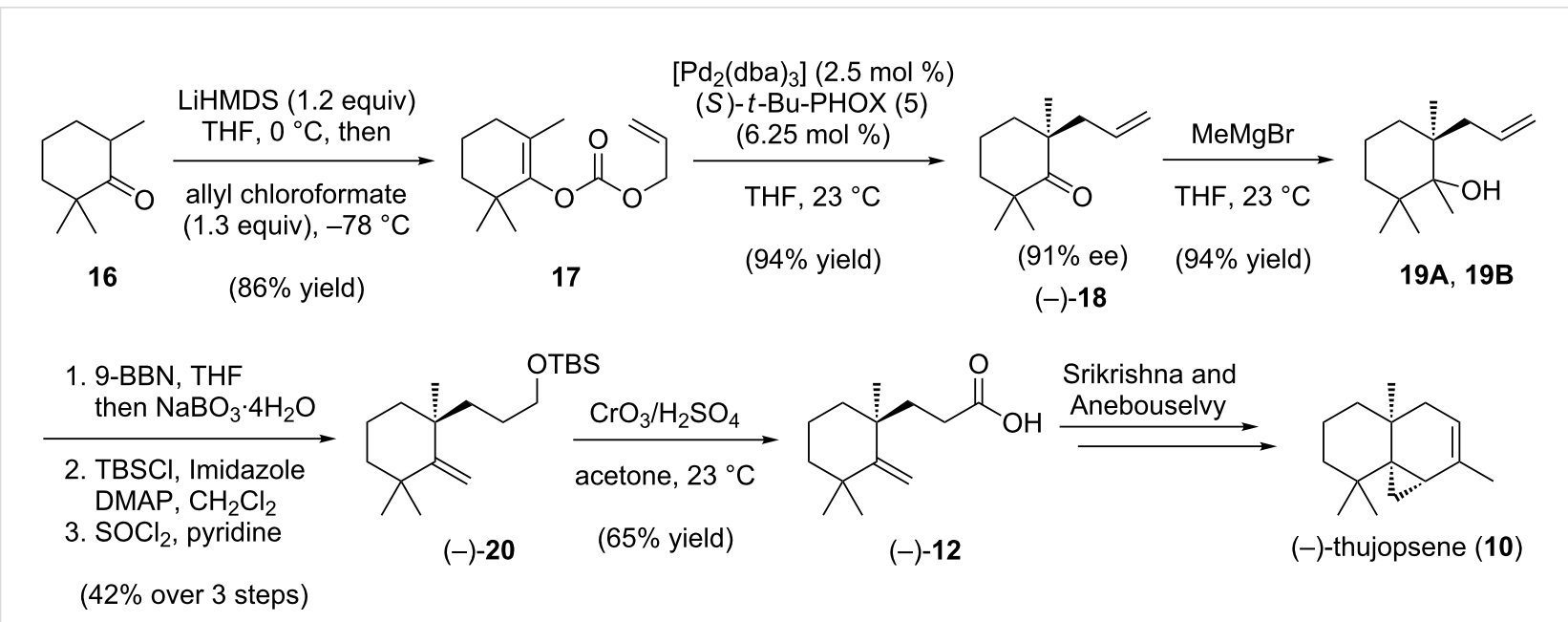

Scheme 3: Formal total synthesis of (-)-thujopsene.

dration, affording methylene cyclohexane (-)-20. Treatment of this silyl ether with Jones reagent simultaneously cleaved the silyl group and oxidized the resulting alcohol, furnishing carboxylic acid (-)-12 in 65\% yield. With this enantioenriched acid in hand, the formal total synthesis of (-)-thujopsene (10) is completed in only 9 steps from trimethylcyclohexanone $\mathbf{1 6}$.

\section{B) Quinic acid}

(-)-Quinic acid (21) [35,36] serves as a useful chiral building block that has been employed in numerous syntheses [37], including our own syntheses of (+)- and (-)-dragmacidin F [3841], and the initial commercial-scale synthesis of Tamiflu [42]. In Renaud's formal total synthesis of (-)-quinic acid (21) [35], a key carboxylic acid $\mathbf{2 2}$ was accessed, intercepting Novak's older synthesis of the natural product (Scheme 4) [36]. To begin, Renaud transformed the chiral glycolic acid ketal $\mathbf{2 3}$ (enantioenriched to $80 \%$ ee) to the more elaborate diene 24 via two diastereoselective alkylations. After a sequence of three reactions including removal of the pinacolone portion of the auxiliary, carboxylic acid 22 could be accessed. Novak's synthesis applied a bromolactonization of $\mathbf{2 2}$ to build in the requisite syn relationship between the carboxylate group and the 3-hydroxy group, ultimately leading to quinic acid.

Unlike the allylic alkylations in Scheme 1, which form allcarbon stereocenters, we envisioned a unique modification of the silyl enol ether version to access nonracemic tertiary alcohols (Scheme 5) [43]. The planned modification would involve the use of dioxanone-derived substrates instead of the prototypical cycloalkanone-derived ones. To demonstrate this new technology in the context of formal total synthesis, we chose to intercept the acid $\mathbf{2 2}$ in the Renaud and Novak routes to quinic acid (21). Conversion of dioxanone 25 to a cyclohexylimine

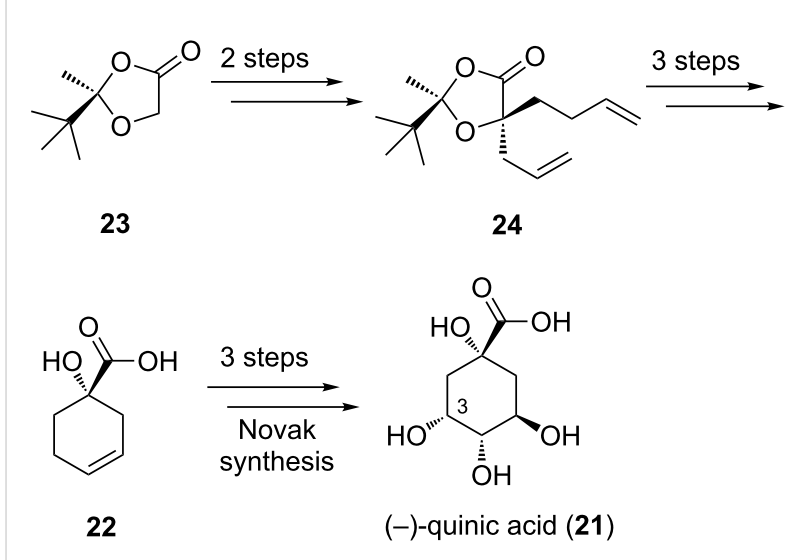

Scheme 4: Renaud's formal total synthesis of (-)-quinic acid.

enabled alkylation via a metalloenamine. On acidic work-up, imine hydrolysis furnished an alkylated dioxanone in good yield. The targeted silyl enol ether $\mathbf{2 6}$ was prepared by thermodynamic silylation in $66 \%$ yield [43]. Optimal conversions and enantioselectivities were achieved from triethylsilyl enol ether 26 on exposure to $\left[\mathrm{Pd}(\mathrm{dmdba})_{2}\right]$ (5 mol \%), $(S)-t$-BuPHOX (5, $5.5 \mathrm{~mol} \%$ ), and diallyl carbonate (1.05 equiv) at $25{ }^{\circ} \mathrm{C}$, in $\mathrm{PhMe}$ with an equivalent of $\mathrm{Bu}_{4} \mathrm{NPh}_{3} \mathrm{SiF}_{2}$ (TBAT) [43]. Recognizing that enantioenriched $\alpha, \omega$-dienes could be transformed into cycloalkenes with a stereocenter remote to the olefin [44], chiral diene 27 was submitted to ring closing metathesis to generate $\mathbf{2 8}$ in $90 \%$ yield and $92 \%$ ee [43]. Cyclohexene $\mathbf{2 8}$ readily undergoes acetonide cleavage and periodic acid oxidation to provide carboxylic acid (S)-22 [43], completing the formal synthesis of (-)-quinic acid (21). Additionally, one could in principle also access the less commercially abundant antipode (+)-quinic acid (21) using the catalyst $(R)-t$-Bu-PHOX. 
<smiles>CC1(C)OCC(=O)CO1</smiles>

25$$
25
$$

1. $\mathrm{CyNH}_{2}, 4 \AA \mathrm{MS}$

2. LDA, 1-iodo-3-butene (53\% over 2 steps)

3. TESCl, $\mathrm{Et}_{3} \mathrm{~N}, \mathrm{Nal}$ $(66 \%$ yield $)$<smiles>CC1(C)OCC(=O)[C@]2(CC=CCC2)O1</smiles>

28

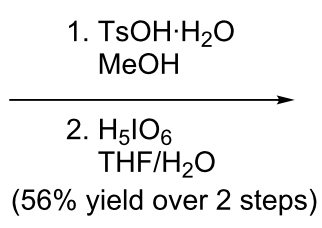

( $56 \%$ yield over 2 steps)<smiles>C=CCCC1=C([O-])COC(C)(C)O1</smiles>

26 diallyl carbonate (6)

(1.05 equiv)

(S)- $t$-Bu-PHOX (5)

$(5.5 \mathrm{~mol} \%)$

$\left[\mathrm{Pd}(\mathrm{dmdba})_{2}\right](5.0 \mathrm{~mol} \%)$

TBAT (7) (1 equiv) PhMe, $25^{\circ} \mathrm{C}$

(83\% yield, $92 \%$ ee)

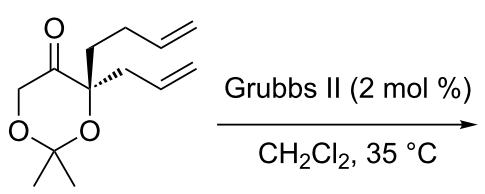

27
(90\% yield, $92 \%$ ee)<smiles>O=C(O)[C@]1(O)C[C@@H](O)[C@H](O)[C@H](O)C[C@@]1(O)C(=O)O[W]</smiles>

(21)

Scheme 5: Formal total synthesis of (-)-quinic acid.

\section{C) Dysidiolide}

Dysidiolide (29, Scheme 6) was isolated from the marine sponge Dysidea etheria and found to have inhibitory activity toward protein phosphatase cde25, with an $\mathrm{IC}_{50}$ value of $9.4 \mu \mathrm{M}$ [45]. This enzyme is a member of the protein family responsible for dephosphorylation of cyclin-dependent kinases [46]. Thus, inhibitors of cdc25 might allow for targeted cellcycle disruption [45]. The relative stereochemistry of dysidiolide (29) was determined via single-crystal X-ray diffraction analysis, revealing a molecule with six stereocenters, two of which are quaternary carbons [45]. Several groups have reported total syntheses of this natural product [47-53], three of which are enantioselective [54-56].

In Danishefsky's approach to racemic dysidiolide, the cyclohexene ring of $\mathbf{3 0}$ was installed via diastereoselective Diels-Alder reaction of a transient dioxolenium dienophile and chiral vinylcyclohexene 31 [48]. Triene 31 was prepared from $\alpha$-quaternary ketone $( \pm)$-32 in racemic form. We anticipated the interception of (-)-32 [57] in Danishefsky's route using enantioselective palladium-catalyzed allylic alkylation to set the quaternary stereocenter.

The formal total synthesis of (-)-dysidiolide (29) commenced with known allyl $\beta$-ketoester 4 (Scheme 7), which was converted to 2-allyl-2-methylcyclohexanone (2) in $85 \%$ yield and $88 \%$ ee [58] with a catalytic amount of $\left[\mathrm{Pd}_{2}(\mathrm{dba})_{3}\right]$ and $(S)$ $t$-BuPHOX (5, Scheme 1). The allyl ketone was enriched to $98 \%$ ee via recrystallization of semicarbazone 33 [59]. Using the Grubbs $2^{\text {nd }}$ generation metathesis catalyst, allyl ketone (-)-2 was crossed with methyl vinyl ketone in $62 \%$ yield [34]. Reduction of enone 34 was achieved in the presence of $\mathrm{Pd} / \mathrm{C}$ with $\mathrm{H}_{2}$<smiles>C=C(C)CCC[C@]1(C)CCC[C@]2(C)[C@H]1CC[C@H](C)[C@]2(C)C[C@H](O)C1=CC(=O)OC1O</smiles>

(-)-dysidiolide (29)<smiles>C=CCCC[C@]1(C)CCCC=C1C=C</smiles>

31

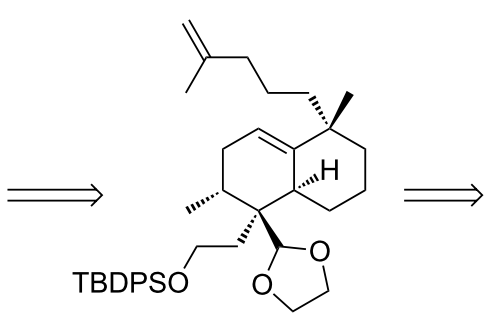

30<smiles>C=C(C)CCC[C@]1(C)CCCCC1=O</smiles>

32
Scheme 6: Danishefsky's approach to ( \pm )-dysidiolide.

in EtOAc to furnish diketone 35 [34]. Chemoselective Wittig mono-olefination of $\mathbf{3 5}$ provided $\omega$-enone (-)-32, spectroscopically identical to the material in Danishefsky's racemic synthesis. This formal synthesis shows the power of the enantioselective allylic alkylation to access formerly racemic constructs as single enantiomers; Danishefsky's synthesis is now rendered enantioselective.

\section{D) Aspidospermine}

The aspidosperma alkaloids have garnered much attention as beautiful targets for the synthetic chemist. Most of the 250-plus 


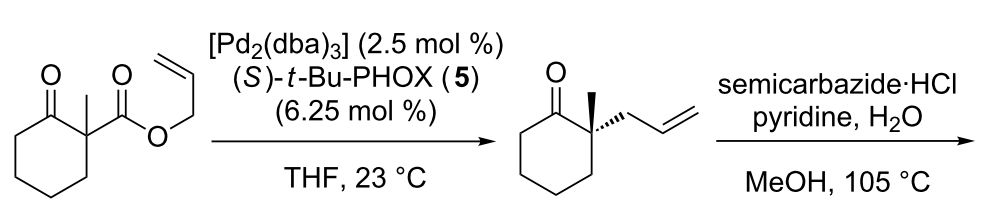

4

2

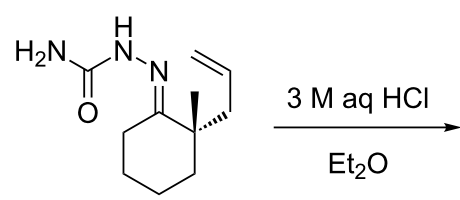

33

(recrystallized)<smiles>C=CC[C@]1(C)CCCCC1=O</smiles>

2

Grubbs II (5 mol\%) methyl vinyl ketone

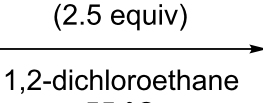

$55^{\circ} \mathrm{C}$

(62\% yield)<smiles>CC(=O)/C=C/C[C@]1(C)CCCCC1=O</smiles>

34

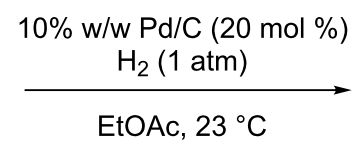

$(61 \%$ yield $)$<smiles>CC(=O)CCC[C@]1(C)CCCCC1=O</smiles>

35<smiles>C=C(C)CCC[C@]1(C)CCCC(=O)C1Br</smiles><smiles>C=C(C)CCC[C@]1(C)CCC[C@]2(C)C1=CC[C@H](C)[C@]2(C)C[C@H](O)C1=CC(=O)OC1O</smiles>

(-)-dysidiolide (29)

Scheme 7: Formal total synthesis of (-)-dysidiolide.

compounds in this class share a pentacyclic core, from the clinical anticancer therapeutics vincristine and vinblastine to the simpler aspidospermidine [60]. To address the challenging synthetic features of the aspidosperma alkaloids, many clever synthetic approaches have been reported [61,62]. One popular target in this family is aspidospermine (36, Scheme 8). Although its medicinal potency is inferior to other members of the class, this alkaloid has served as a proving ground for many synthetic chemists.

In 1989, Meyers reported an enantioselective synthesis of the $(4 \mathrm{a} S, 8 \mathrm{a} R, 8 S)$-hydrolilolidone core $37[63,64]$ present in aspidospermine (36), and thus a formal total synthesis of the alkaloid itself, intercepting Stork's classic route [61]. One precursor described in the core synthesis is enone $\mathbf{3 8}$, which bears the quaternary stereocenter of the natural product. Contrasting Meyers' approach, which employed a chiral auxiliary as part of 39, we thought a catalytic enantioselective alkylation strategy would be ideal for a formal total synthesis of natural (-)-aspidospermine (36) via the antipode of $\mathbf{3 8}$.

The formal synthesis began with 1,3-cyclohexanedione (40), which was converted to isobutyl vinylogous ether $\mathbf{4 1}$ under acid

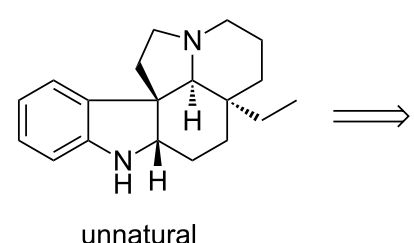

(+)-aspidospermine (36)<smiles>C=CC[C@]1(CC)C=CC(=O)CC1</smiles>

38

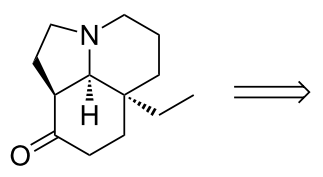

hydrolilolidone core 37
39

Scheme 8: Meyers' approach to unnatural (+)-aspidospermine.

promotion (Scheme 9) [65]. The $\beta$-ketoester 42 was prepared using a two-step sequence of acylation and alkylation, then treated with the $(S)$ - $t$-Bu-PHOX catalyst system (with $\left.\left[\mathrm{Pd}(\mathrm{dmdba})_{2}\right]\right)$ to generate $(+)-43$ in $86 \%$ ee. The challenge of installing the $\gamma$-stereocenter of the target $\mathbf{3 8}$ was addressed as follows: $\mathrm{LiAlH}_{4}$ treatment of (+)-43 gave exclusive 1,2-reduction. When the crude product was hydrolyzed, $\beta$-elimination 


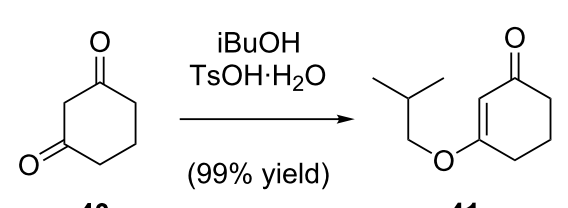

41 \begin{tabular}{l} 
1. LDA, PhMe \\
then 41 \\
then allyl chloroformate \\
\hline 2. $\mathrm{Cs}_{2} \mathrm{CO}_{3}$, iodoethane \\
$\mathrm{CH}_{3} \mathrm{CN}, 65^{\circ} \mathrm{C}$
\end{tabular}

( $60 \%$ yield over 2 steps)<smiles>C=CCOC(=O)C1(C(C)=O)CCC(OCC(C)C)C=C1C</smiles>

42
$\left[\mathrm{Pd}(\mathrm{dmdba})_{2}\right](5.00 \mathrm{~mol} \%)$

(S)- $t$-Bu-PHOX (5)

$(6.25 \mathrm{~mol} \%)$

THF, $50^{\circ} \mathrm{C}$

( $82 \%$ yield, $86 \%$ ee)<smiles>C=CC[C@]1(CC)CCC(OCC(C)C)=CC1=O</smiles>

$(+)-43$

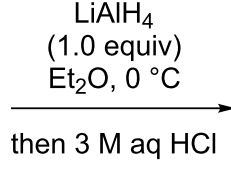

(75\% yield)

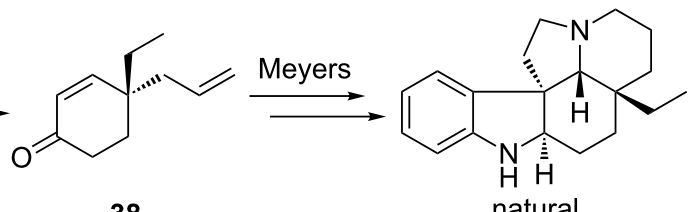

38

(-)-aspidospermine (36)

Scheme 9: Formal total synthesis of (-)-aspidospermine.

gave the desired enone $\mathbf{3 8}$. The overall formal synthesis represents a rare example of enantioselective Stork-Danheiser chemistry $[66,67]$.

\section{E) Rhazinilam}

(-)-Rhazinilam (44) has been isolated from various plants including Rhazya strica decaisne [68], Melodinus australis [69], and Kopsia singapurensis [70]. Shortly after the first isolation, its structure was elucidated by single crystal X-ray diffraction analysis [71]. It features a tetracyclic scaffold with a ninemembered ring and an all-carbon quaternary stereocenter. This alkaloid is a microtubule-disrupting agent that displays similar cellular effects to paclitaxel $[72,73]$. Because of its biological activities and potential pharmaceutical use, many groups have pursued its total synthesis [74-77], including a number of enantioselective syntheses [78-82].

In 2001, Magnus reported a total synthesis of rhazinilam in racemic form (Scheme 10) [83]. In their approach, the first retrosynthetic disconnection of the amide $\mathrm{C}-\mathrm{N}$ bond in the ninemembered ring led to tricyclic compound $\mathbf{4 5}$. The pyrrole ring of $\mathbf{4 5}$ was formed by intramolecular condensation of cinnamyl amide 46, which is prepared via union of quaternary piperidinone 47 and cinnamyl electrophile 48. We envisioned that our allylic alkylation of lactam enolates would furnish enantioenriched piperidinone 47 , and thus a single enantiomer of rhazinilam may be prepared.

The formal synthesis of (+)-rhazinilam commenced with palladium-catalyzed decarboxylative allylic alkylation of known carboxy-lactam 49 to afford benzoyl-protected piperidinone $\mathbf{5 0}$ in $97 \%$ yield and $99 \%$ ee (Scheme 11) [84]. Cleavage of the benzoyl group under basic conditions furnished piperidinone (+)-47 [84], which can be advanced to (+)-rhazinilam via

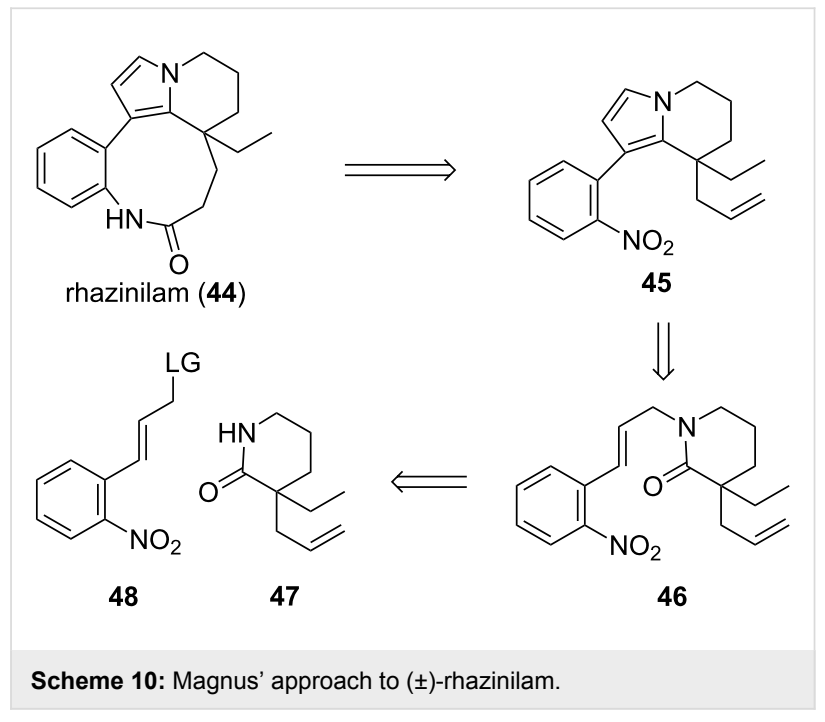

Magnus' route. This formal synthesis demonstrates the utility of our recently developed asymmetric lactam alkylation chemistry.

\section{F) Quebrachamine}

Quebrachamine (51) is an indole alkaloid isolated from the Aspidosperma quebracho tree bark [60]. It has been found to possess adrenergic blocking activities for a variety of urogenital tissues [85]. Structurally, it features a tetracycle including an indole nucleus, a 9-membered macrocycle, and an all-carbon quaternary stereocenter. Due to its structural complexity and biological activities, quebrachamine has received considerable attention from the chemistry community. A number of total syntheses have been reported [86-88], with several examples of asymmetric syntheses [89-91].

In 2007, Amat reported an enantioselective total synthesis of quebrachamine (Scheme 12) [92]. In their planning, disconnec- 
<smiles>C=CCOC(=O)C1(C)CCCN(C(=O)c2ccccc2)C1=O</smiles>

49

$\left[\mathrm{Pd}_{2}(\text { pmdba })_{3}\right](5 \mathrm{~mol} \%)$

(S)-( $\left.\mathrm{CF}_{3}\right)_{3}$ - $t$-Bu-PHOX (12.5 mol \%)

toluene, $40^{\circ} \mathrm{C}$<smiles>C=CC[C@]1(CC)CCCN(C(=O)c2ccccc2)C1=O</smiles>

50

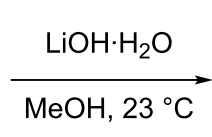

(96\% yield)<smiles>C=CC[C@]1(CC)CCCNC1=O</smiles>

$(+)-47$<smiles>CC[C@]12CCCn3ccc(c31)-c1ccccc1NC(=O)CC2</smiles>

(+)-rhazinilam (44)

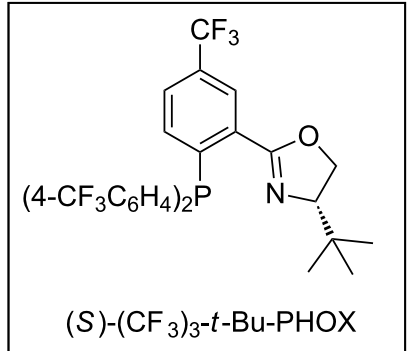

Scheme 11: Formal total synthesis of (+)-rhazinilam.

tion at the macrocycle led to amide 52, which was prepared from 3,3-disubstituted piperidine 53. The all-carbon quaternary stereocenter in $\mathbf{5 3}$ was installed by double alkylation of lactam $\mathbf{5 5}$, using an auxiliary to control the stereoselectivity. We envisioned that an alternative way of constructing this motif would again make use of our recently developed palladium-catalyzed asymmetric alkylation of lactam enolates.<smiles>C=C=CCC1CCN2CCC[C@@](CC)(CCc3[nH]c4ccccc4c31)C2</smiles>

(-)-quebrachamine (51)<smiles>CC[C@]1(CC(C)=O)CCCN(C(=O)Cc2c[nH]c3ccccc23)C1</smiles><smiles>C=C</smiles><smiles>O=C1CCC[C@H]2OC[C@H](c3ccccc3)N12</smiles>

55

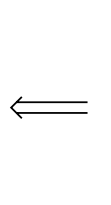<smiles>C=CC[C@]1(CC)CC[C@H]2OCC(c3ccccc3)N2C1=O</smiles>

54

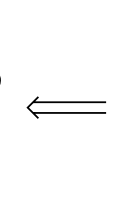<smiles>CCC1(CC)CCCN(C(=O)OC(C)(C)C)C1</smiles>

53

\section{Scheme 12: Amat's approach to (-)-quebrachamine.}

The formal synthesis of (+)-quebrachamine commenced with benzoyl lactam 50 (Scheme 13), which was prepared in excellent yield and ee by alkylation of carboxy-lactam 49 (see Scheme 11) [84]. Oxidative cleavage of the terminal double bond and subsequent reduction with $\mathrm{LiAlH}_{4}$ afforded $N$-benzylpiperidine-alcohol 56 [84]. Hydrogenolysis of the $\mathrm{N}$-benzyl group and re-protection with di-tert-butyl dicarbonate
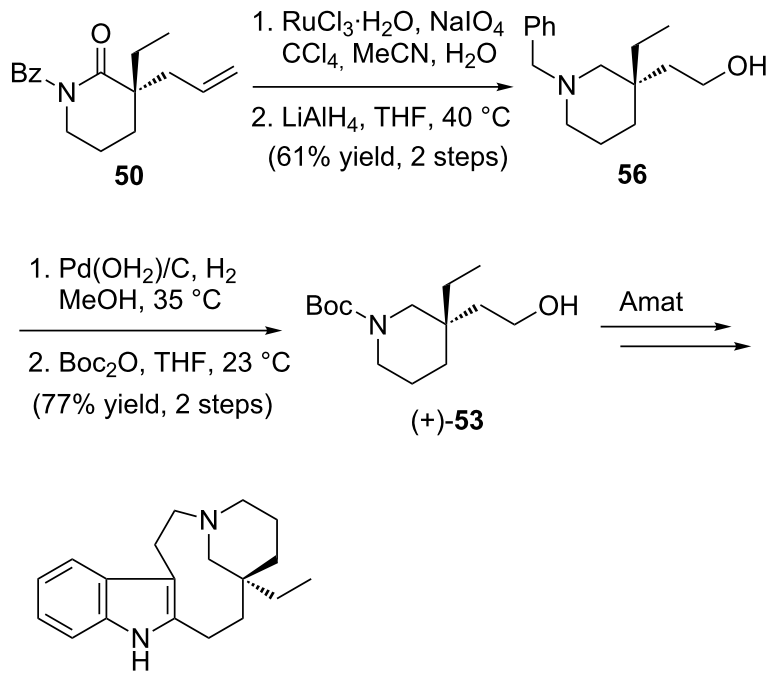

(+)-quebrachamine (51)

Scheme 13: Formal total synthesis of $(+)$-quebrachamine.

furnished $N$-boc piperidine-alcohol (+)-53 [84], thus intercepting an intermediate in Amat's synthesis of quebrachamine.

\section{G) Vincadifformine}

Vincadifformine (59) was isolated in both enantioenriched and racemic forms from the leaves and roots of Rhazya stricta in 1963 [93]. Not only is it a representative member of the Aspidosperma alkaloid family, but it also holds particular significance as a valuable precursor to pharmaceutically important vincamine, vincamone, and cavinton [94-97]. The molecule has a fused pentacyclic framework with three contiguous stereocenters, two of which are all-carbon quaternary centers. The medicinal relevance and structural complexity of vincadifformine 
have led to a large number of total syntheses [98-104], including several enantioselective examples [105-108].

Recently, Pandey reported a highly efficient synthesis of (+)vincadifformine (Scheme 14) [106]. The key step in the synthesis was an iminium ion cascade reaction that formed the fused ring systems by coupling 3,3-disubstituted tetrahydropyridine $\mathbf{5 7}$ with indole derivative $\mathbf{5 8}$. The former coupling partner was derived from chiral $\alpha$-quaternary lactam $\mathbf{6 0}$, which was constructed using a chiral auxiliary strategy. We envisioned that chiral lactam 60 could again be readily accessed by our palladium-catalyzed enantioselective alkylation chemistry.

The formal synthesis of (-)-vincadifformine commenced with ruthenium-catalyzed isomerization of the terminal olefin moiety in unprotected piperidinone $(+)-47$ (made previously in the formal synthesis of $(+)$-rhazinilam shown in Scheme 11) to produce internal olefin 63 (Scheme 15) [109]. Ozonolysis of the double bond furnished aldehyde 64, which was reduced under Luche conditions to alcohol 65, a compound identical in structure and enantiomeric to the intermediate employed by Pandey in the synthesis of $(+)$-vincadifformine.

\section{Conclusion}

The development of a series of Pd-catalyzed methods for constructing stereogenic quaternary carbons has provided two generations of building blocks (Scheme 16). The described derivatization enabled the formal total syntheses of an array of classic natural products including sugar derivatives, terpenes, and alkaloids, adding significantly to the growing list of uses for this powerful $\mathrm{C}-\mathrm{C}$ bond construction. An efficient route to the sesquiterpenoid (-)-thujopsene (10) has been delineated, allowing access to the compound's natural antipode. Our lab's novel approach to (-)-quinic acid (21) allowed access to either

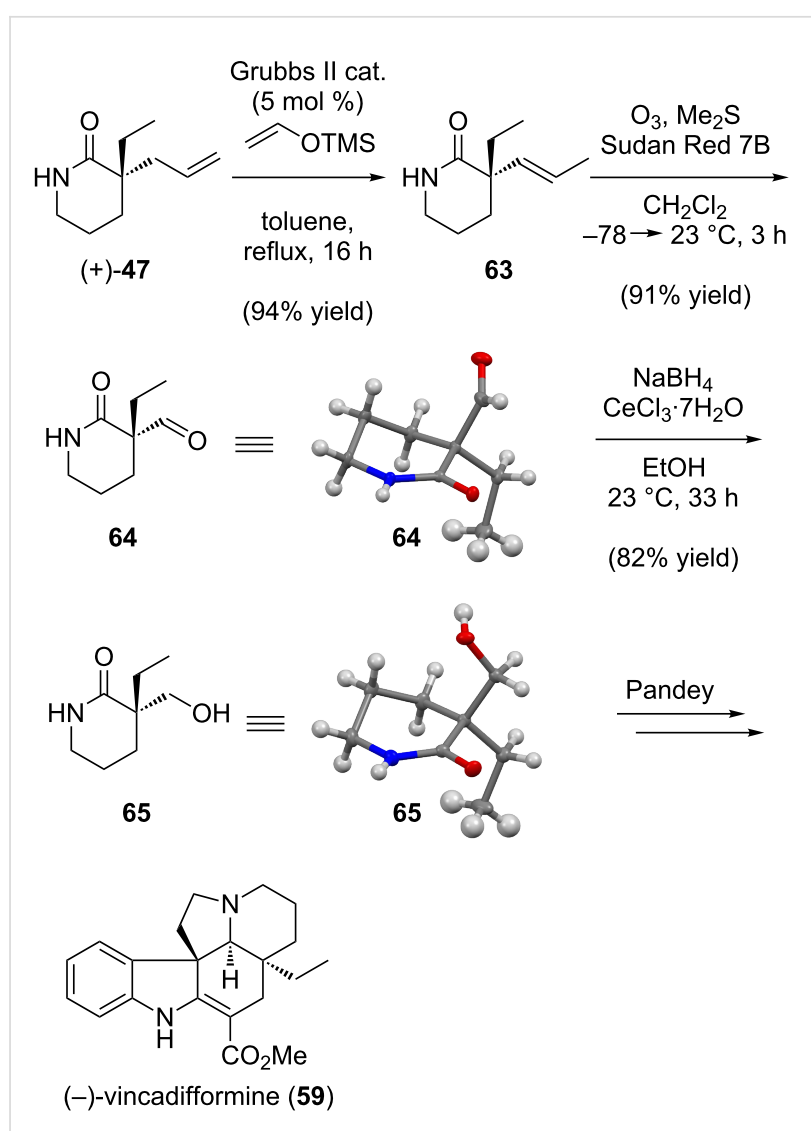

Scheme 15: Formal total synthesis of (-)-vincadifformine.

enantiomer of this important substance. We have also intercepted a key intermediate in Danishefsky's synthesis of $( \pm)$ dysidiolide (29), rendering the former racemic route enantioselective. Additionally, a rapid approach to a compound in Meyers' formal synthesis of (+)-aspidospermine (36) granted access to the natural product without the use of a chiral auxil-<smiles>CC[C@]1(CO[S+](C)(C)C)C=NCCC1</smiles>

57<smiles>C=CC[C@@]1(CC)CCCNC1=O</smiles>

60
58<smiles>C=CC=CC1(C(=O)OC)C=CCNC1=O</smiles>

(+)-vincadifformine (59) 

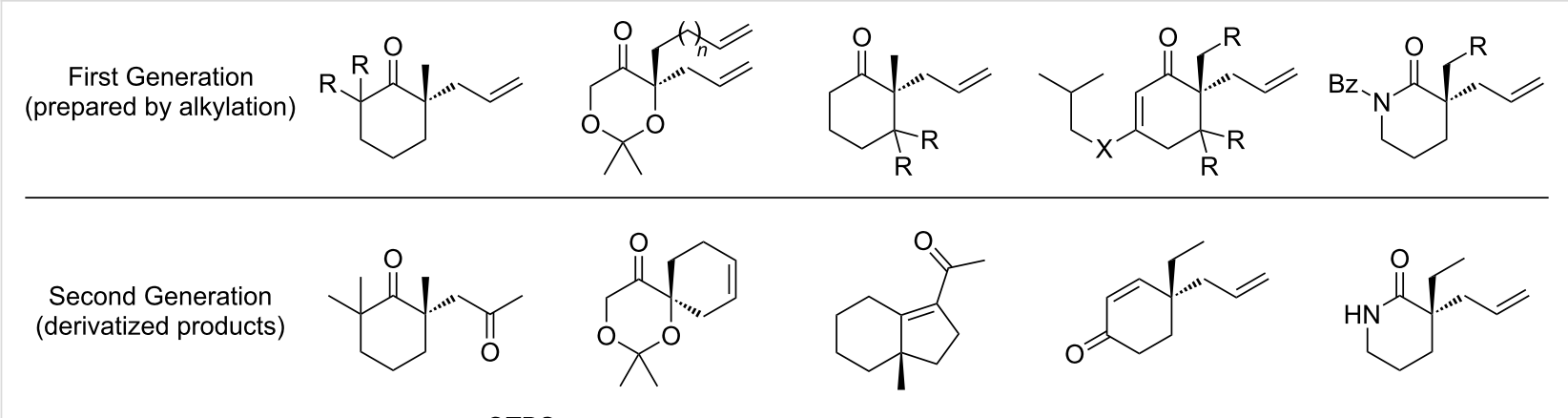<smiles>C=CCC1(CC)C=CC(=O)CC1</smiles><smiles>C=CCC1(CC)CCCNC1=O</smiles><smiles>C=C1C(C)(C)CCC[C@]1(C)CCC[SeH2]</smiles><smiles>O=C(CO)C1(O)CC=CCC1</smiles><smiles>CC12CCCCC1=CC(=O)CC2</smiles><smiles>COC(=O)CC[C@]1(C)C=CC(=O)CC1</smiles><smiles>C=CC[C@]1(CC)CCCNC1</smiles><smiles>C=C1C(C)(C)CCC[C@]1(C)CCC(=O)O</smiles><smiles>O=C(O)C1(O)CC=CCC1</smiles><smiles>C=CC[C@]1(C)CCCCC(=O)O1</smiles><smiles>C=CC[C@]1(C)C=C(C(C)=O)CC1</smiles><smiles>C=CC[C@]1(CC(=C)CO[SbH3])CCC(=O)C(C)=C1CC(=O)OC</smiles><smiles>CC1(C)CCCC2(C)CC(=O)C=C12</smiles><smiles>CC1=CC[C@]2(CCCCC2=O)C1</smiles><smiles>C=C(C)CCC[C@]1(C)CCCCC1=O</smiles><smiles>CC[C@@]1(CCO)CCCN(Cc2ccccc2)C1</smiles><smiles>CC[C@]1(CO)CCCNC1=O</smiles><smiles>COC(=O)/C=C/C[C@]1(C)C(=O)CCCC12OCCO2</smiles><smiles>CC1=C(S)CC[C](CO)C1=O</smiles><smiles>CC1=C(S)CC[C@H](C=O)C1=O</smiles><smiles>CC1=C(C)C[C@@]2(CC1)CC(Cl)=C(C)CC2=O</smiles><smiles>CC[C@]1(C=O)CCCNC1=O</smiles>

Scheme 16: Two generations of building blocks.

iary. Finally, we have demonstrated the application of lactam alkylation products in the catalytic asymmetric syntheses of $(+)-$ rhazinilam (44), (+)-quebrachamine (51), and (-)-vincadifformine (59). The powerful catalytic enantioselective allylic alkylation will undoubtedly enable new synthetic endeavors in the context of both academic and industrial research.

\section{Supporting Information}

Supporting information features experimental procedures, characterization data of synthesized compounds, copies of ${ }^{1} \mathrm{H}$ and ${ }^{13} \mathrm{C}$ NMR spectra, and single crystal structure data.

\section{Supporting Information File 1}

Experimental data, NMR spectra and X-ray data. [http://www.beilstein-journals.org/bjoc/content/ supplementary/1860-5397-10-261-S1.pdf]

\section{Acknowledgements}

We are grateful to NIH (R01GM080269), Amgen, the Gordon and Betty Moore Foundation, and Caltech for funding. We also thank the Caltech Minorities Undergraduate Research Fellowship program, PREM program, Eli Lilly, the Resnick Sustainability Institute at Caltech (fellowship for Y. L.), and the Swiss National Science Foundation (SNSF, fellowship for M. L.). Dr. Michael L. Krout and Dr. David E. White are acknowledged for preliminary experimental work related to their results. Dr. Michael Takase (Caltech) and Larry Henling (Caltech) are gratefully acknowledged for X-ray crystallographic structural determination.

\section{References}

1. Trost, B. M.; Jiang, C. Synthesis 2006, 369-396. doi:10.1055/s-2006-926302

2. Mohr, J. T.; Stoltz, B. M. Chem. - Asian J. 2007, 2, 1476-1491. doi:10.1002/asia.200700183

3. Behenna, D. C.; Mohr, J. T.; Sherden, N. H.; Marinescu, S. C.; Harned, A. M.; Tani, K.; Seto, M.; Ma, S.; Novák, Z.; Krout, M. R.; McFadden, R. M.; Roizen, J. L.; Enquist, J. A., Jr.; White, D. E.; Levine, S. R.; Petrova, K. V.; Iwashita, A.; Virgil, S. C.; Stoltz, B. M. Chem. - Eur. J. 2011, 17, 14199-14223. doi:10.1002/chem.201003383

4. McFadden, R. M.; Stoltz, B. M. J. Am. Chem. Soc. 2006, 128, 7738-7739. doi:10.1021/ja061853f 
5. White, D. E.; Stewart, I. C.; Grubbs, R. H.; Stoltz, B. M. J. Am. Chem. Soc. 2008, 130, 810-811. doi:10.1021/ja710294k

6. Enquist, J. A., Jr.; Stoltz, B. M. Nature 2008, 453, 1228-1231. doi:10.1038/nature07046

7. Enquist, J. A., Jr.; Virgil, S. C.; Stoltz, B. M. Chem. - Eur. J. 2011, 17, 9957-9969. doi:10.1002/chem.201100425

8. Enquist, J. A., Jr.; Stoltz, B. M. Nat. Prod. Rep. 2009, 26, 661-680. doi:10.1039/B811227B

9. Levine, S. R.; Krout, M. R.; Stoltz, B. M. Org. Lett. 2009, 11, 289-292. doi:10.1021/ol802409h

10. Petrova, K. V.; Mohr, J. T.; Stoltz, B. M. Org. Lett. 2009, 11, 293-295. doi:10.1021/ol802410t

11. White, D. E.; Stewart, I. C.; Seashore-Ludlow, B. A.; Grubbs, R. H.; Stoltz, B. M. Tetrahedron 2010, 66, 4668-4686. doi:10.1016/j.tet.2010.04.128

12. Day, J. J.; McFadden, R. M.; Virgil, S. C.; Kolding, H.; Alleva, J. L.; Stoltz, B. M. Angew. Chem., Int. Ed. 2011, 50, 6814-6818. doi:10.1002/anie.201101842

13. Wei, Y.; Zhao, D.; Ma, D. Angew. Chem., Int. Ed. 2013, 52, 12988-12991. doi:10.1002/anie.201307788

14. Xu, Z.; Wang, Q.; Zhu, J. J. Am. Chem. Soc. 2013, 135 , 19127-19130. doi:10.1021/ja4115192

15. Hu, Q.-Y.; Zhou, G.; Corey, E. J. J. Am. Chem. Soc. 2004, 126, 13708-13713. doi:10.1021/ja046154m

16. Ko, S. Y.; Lee, A. W. M.; Masamune, S.; Reed, L. A., III; Sharpless, K. B.; Walker, F. J. Science 1983, 220, 949-951. doi:10.1126/science.220.4600.949

17. Inamori, Y.; Morita, Y.; Sakagami, Y.; Okabe, T.; Ishida, N. Biocontrol Sci. 2006, 11, 49-54. doi:10.4265/bio.11.49

18. Chetty, G. L.; Dev, S. Tetrahedron Lett. 1965, 6, 3773-3776. doi:10.1016/S0040-4039(01)99562-0

19. Itô, S.; Endo, K.; Honma, H.; Ota, K. Tetrahedron Lett. 1965, 6, 3777-3781. doi:10.1016/S0040-4039(01)99563-2

20. Oh, I.; Yang, W.-Y.; Park, J.; Lee, S.; Mar, W.; Oh, K.-B.; Shin, J. Arch. Pharmacal Res. 2011, 34, 2141-2147. doi:10.1007/s12272-011-1218-5

21. Yano, M. J. Soc. Chem. Ind., Jpn. 1913, 16, 443-463.

22. Uchida, S. J. Soc. Chem. Ind., Jpn. 1928, 31, 501-503.

23. Miyazaki, Y. Mokuzai Gakkaishi 1996, 42, 624-626.

24. Hiramatsu, Y.; Miyazaki, Y. J. Wood Sci. 2001, 47, 13-17. doi:10.1007/BF00776639

25. Dauben, W. G.; Ashcraft, A. C. J. Am. Chem. Soc. 1963, 85, 3673-3676. doi:10.1021/ja00905a032

26. Büchi, G.; White, J. D. J. Am. Chem. Soc. 1964, 86, 2884-2887 doi:10.1021/ja01068a024

27. Mori, K.; Ohki, M.; Kobayashi, A.; Matsui, M. Tetrahedron 1970, 26, 2815-2819. doi:10.1016/S0040-4020(01)92857-1

28. McMurry, J. E.; Blaszczak, L. C. J. Org. Chem. 1974, 39, 2217-2222. doi:10.1021/jo00929a017

29. Branca, S. J.; Lock, R. L.; Smith, A. B., III. J. Org. Chem. 1977, 42, 3165-3168. doi:10.1021/jo00439a012

30. Johnson, C. R.; Barbachyn, M. R. J. Am. Chem. Soc. 1982, 104, 4290-4291. doi:10.1021/ja00379a060

31. Lee, E.; Shin, I.-J.; Kim, T.-S. J. Am. Chem. Soc. 1990, 112, 260-264. doi:10.1021/ja00157a041

32. Zhang, C. X.; Fang, L. J.; Bi, F. Q.; Li, Y. L. Chin. Chem. Lett. 2008, 19, 256-258. doi:10.1016/j.cclet.2008.01.009

33. Srikrishna, A.; Anebouselvy, K. J. Org. Chem. 2001, 66, 7102-7106. doi:10.1021/j00105484
34. Behenna, D. C.; Stoltz, B. M. J. Am. Chem. Soc. 2004, 126 15044-15045. doi:10.1021/ja044812x

35. Rapado, L. P.; Bulugahapitiya, V.; Renaud, P. Helv. Chim. Acta 2000, 83, 1625-1632.

doi:10.1002/1522-2675(20000705)83:7<1625::AID-HLCA1625>3.0.C O;2-W

36. Wolinsky, J.; Novak, R.; Vasilev, R. J. Org. Chem. 1964, 29, 3596-3598. doi:10.1021/jo01035a038

37. Barco, A.; Benetti, S.; De Risi, C.; Marchetti, P.; Pollini, G. P.; Zanirato, V. Tetrahedron: Asymmetry 1997, 8, 3515-3545. doi:10.1016/S0957-4166(97)00471-0

38. Garg, N. K.; Caspi, D. D.; Stoltz, B. M. J. Am. Chem. Soc. 2004, 126, 9552-9553. doi:10.1021/ja046695b

39. Garg, N. K.; Caspi, D. D.; Stoltz, B. M. J. Am. Chem. Soc. 2005, 127, 5970-5978. doi:10.1021/ja050586v

40. Garg, N. K.; Stoltz, B. M. Chem. Commun. 2006, 3769-3779. doi:10.1039/B605929E

41. Garg, N. K.; Caspi, D. D.; Stoltz, B. M. Synlett 2006, 3081-3087. doi:10.1055/s-2006-951492

42. Rohloff, J. C.; Kent, K. M.; Postich, M. J.; Becker, M. W.; Chapman, H. H.; Kelly, D. E.; Lew, W.; Louie, M. S.; McGee, L. R.; Prisbe, E. J.; Schultze, L. M.; Yu, R. H.; Zhang, L. J. Org. Chem. 1998, 63, 4545-4550. doi:10.1021/jo980330q

43. Seto, M.; Roizen, J. L.; Stoltz, B. M. Angew. Chem., Int. Ed. 2008, 47, 6873-6876. doi:10.1002/anie.200801424

44. Scholl, M.; Ding, S.; Lee, C. W.; Grubbs, R. H. Org. Lett. 1999, 1, 953-956. doi:10.1021/ol990909q

45. Gunasekera, S. P.; McCarthy, P. J.; Kelly-Borges, M. J. Am. Chem. Soc. 1996, 118, 8759-8760. doi:10.1021/ja961961+

46. Millar, J. B. A.; Russel, P. Cell 1992, 68, 407-410. doi:10.1016/0092-8674(92)90177-E

47. Boukouvalas, J.; Cheng, Y.-X.; Robichaud, J. J. Org. Chem. 1998, 63 , 228-229. doi:10.1021/jo972208h

48. Magnuson, S. R.; Sepp-Lorenzino, L.; Rosen, N.; Danishefsky, S. J. J. Am. Chem. Soc. 1998, 120, 1615-1616. doi:10.1021/ja9740428

49. Miyaoka, H.; Kajiwara, Y.; Yamada, Y. Tetrahedron Lett. 2000, 41, 911-914. doi:10.1016/S0040-4039(99)02175-9

50. Takahashi, M.; Dodo, K.; Hashimoto, Y.; Shirai, R. Tetrahedron Lett. 2000, 41, 2111-2114. doi:10.1016/S0040-4039(00)00078-2

51. Paczkowski, R.; Maichle-Mössmer, C.; Maier, M. E. Org. Lett. 2000, 2, 3967-3969. doi:10.1021/ol006742e

52. Miyaoka, H.; Yamada, Y. Bull. Chem. Soc. Jpn. 2002, 75, 203-222. doi:10.1246/bcsj.75.203

53. Demeke, D.; Forsyth, C. J. Tetrahedron 2002, 58, 6531-6544. doi:10.1016/S0040-4020(02)00663-4

54. Corey, E. J.; Roberts, B. E. J. Am. Chem. Soc. 1997, 119, 12425-12431. doi:10.1021/ja973023v

55. Miyaoka, H.; Kajiwara, Y.; Hara, Y.; Yamada, Y. J. Org. Chem. 2001, 66, 1429-1435. doi:10.1021/jo0015772

56. Jung, M. E.; Nishimura, N. Org. Lett. 2001, 3, 2113-2115. doi:10.1021/ol016073k

57. Das, P. P.; Lysenko, I. L.; Cha, J. K. Angew. Chem., Int. Ed. 2011, 50, 9459-9461. doi:10.1002/anie.201104331

58. Mohr, J. T.; Behenna, D. C.; Harned, A. M.; Stoltz, B. M. Angew. Chem., Int. Ed. 2005, 44, 6924-6927. doi:10.1002/anie.200502018

59. Mohr, J. T.; Krout, M. R.; Stoltz, B. M. Org. Synth. 2009, 86, 194-211.

60. Saxton, J. E. Alkaloids of the Aspidospermine Group. In The Alkaloids; Cordell, G. A., Ed.; Academic Press: San Diego, 1998; Vol. 51, pp 2-198. 
61. Stork, G.; Dolfini, J. E. J. Am. Chem. Soc. 1963, 85, 2872-2873. doi:10.1021/ja00901a061

62. Ban, Y.; Sato, Y.; Inoue, I.; Nagai, M.; Oishi, T.; Terashima, M.; Yonematsu, O.; Kanaoka, Y. Tetrahedron Lett. 1965, 6, 2261-2268. doi:10.1016/S0040-4039(00)70368-6

63. Meyers, A. I.; Berney, D. J. Org. Chem. 1989, 54, 4673-4676. doi:10.1021/jo00280a040

64. Lawton, G.; Saxton, J. E.; Smith, A. J. Tetrahedron 1977, 33, 1641-1653. doi:10.1016/0040-4020(77)80177-4

65. Spessard, S. J.; Stoltz, B. M. Org. Lett. 2002, 4, 1943-1946. doi:10.1021/ol025968+

66. Stork, G.; Danheiser, R. L. J. Org. Chem. 1973, 38, 1775-1776. doi:10.1021/jo00949a048

67. Bennett, N. B.; Hong, A. Y.; Harned, A. M.; Stoltz, B. M. Org. Biomol. Chem. 2012, 10, 56-59. doi:10.1039/C1OB06189E

68. Banerji, A.; Majumder, P. L.; Chatterjee, A. G. Phytochemistry 1970, 9, 1491-1493. doi:10.1016/S0031-9422(00)85265-6

69. Linde, H. H. A. Helv. Chim. Acta 1965, 48, 1822-1842. doi:10.1002/hlca.19650480803

70. Thoison, O.; Guénard, D.; Sévenet, T.; Kan-Fan, C.; Quirion, J.-C.; Husson, H. P.; Deverre, J.-R.; Chan, K. C.; Potier, P. C. R. Acad. Sci. Paris // 1987, 304, 157-160.

71. Abraham, D. J.; Rosenstein, R. D.; Lyon, R. L.; Fong, H. H. S. Tetrahedron Lett. 1972, 13, 909-912. doi:10.1016/S0040-4039(01)84471-3

72. Alazard, J.-P.; Millet-Paillusson, C.; Boyé, O.; Guénard, D.; Chiaroni, A.; Riche, C.; Thal, C. Bioorg. Med. Chem. Lett. 1991, 1, 725-728. doi:10.1016/S0960-894X(01)81056-8

73. Edler, M. C.; Yang, G.; Jung, M. K.; Bai, R.; Bornmann, W. G.; Hamel, E. Arch. Biochem. Biophys. 2009, 487, 98-104. doi:10.1016/j.abb.2009.05.014

74. Kholod, I.; Vallat, O.; Buciumas, A.-M.; Neier, R. Heterocycles 2011, 82, 917-948. doi:10.3987/REV-10-SR(E)2 See for a review.

75. Ratcliffe, A. H.; Smith, G. F.; Smith, G. N. Tetrahedron Lett. 1973, 14, 5179-5184. doi:10.1016/S0040-4039(01)87657-7

76. Johnson, J. A.; Sames, D. J. Am. Chem. Soc. 2000, 122, 6321-6322. doi:10.1021/ja0003223

77. Bowie, A. L., Jr.; Hughes, C. C.; Trauner, D. Org. Lett. 2005, 7, 5207-5209. doi:10.1021/ol052033v

78. Johnson, J. A.; Li, N.; Sames, D. J. Am. Chem. Soc. 2002, 124, 6900-6903. doi:10.1021/ja026130k

79. Banwell, M. G.; Beck, D. A. S.; Willis, A. C. ARKIVOC 2006, No. 3 , 163-174.

80. Liu, Z.; Wasmuth, A. S.; Nelson, S. G. J. Am. Chem. Soc. 2006, 128, 10352-10353. doi:10.1021/ja0629110

81. Gu, Z.; Zakarian, A. Org. Lett. 2010, 12, 4224-4227. doi:10.1021/ol101523z

82. Sugimoto, K.; Toyoshima, K.; Nonaka, S.; Kotaki, K.; Ueda, H.; Tokuyama, H. Angew. Chem., Int. Ed. 2013, 52, 7168-7171. doi:10.1002/anie.201303067

83. Magnus, P.; Rainey, T. Tetrahedron 2001, 57, 8647-8651. doi:10.1016/S0040-4020(01)00859-6

84. Behenna, D. C.; Liu, Y.; Yurino, T.; Kim, J.; White, D. E.; Virgil, S. C.; Stoltz, B. M. Nat. Chem. 2012, 4, 130-133. doi:10.1038/nchem.1222

85. Deutsch, H. F.; Evenson, M. A.; Drescher, P.; Sparwasser, C.; Madsen, P. O. J. Pharm. Biomed. Anal. 1994, 12, 1283-1287. doi:10.1016/0731-7085(94)00066-2
86. Coldham, I.; Burrell, A. J. M.; White, L. E.; Adams, H.; Oram, N. Angew. Chem., Int. Ed. 2007, 46, 6159-6162. doi:10.1002/anie.200701943

87. Bajtos, B.; Pagenkopf, B. L. Eur. J. Org. Chem. 2009, 1072-1077. doi:10.1002/ejoc.200801154

88. Hsu, S.-W.; Cheng, H.-Y.; Huang, A.-C.; Ho, T.-L.; Hou, D.-R. Eur. J. Org. Chem. 2014, 3109-3115. doi:10.1002/ejoc.201400064

89. Temme, O.; Taj, S.-A.; Andersson, P. G. J. Org. Chem. 1998, 63, 6007-6015. doi:10.1021/jo9807417

90. Kozmin, S. A.; Iwama, T.; Huang, Y.; Rawal, V. H. J. Am. Chem. Soc. 2002, 124, 4628-4641. doi:10.1021/ja017863s

91. Sattely, E. S.; Meek, S. J.; Malcolmson, S. J.; Schrock, R. R.; Hoveyda, A. H. J. Am. Chem. Soc. 2009, 131, 943-953. doi:10.1021/ja8084934

92. Amat, M.; Lozano, O.; Escolano, C.; Molins, E.; Bosch, J. J. Org. Chem. 2007, 72, 4431-4439. doi:10.1021/jo070397q

93. Smith, G. F.; Wahid, M. A. J. Chem. Soc. 1963, 4002-4004. doi:10.1039/JR9630004002

94. Szántay, C. Pure Appl. Chem. 1990, 62, 1299-1302. doi:10.1351/pac199062071299

95. Danieli, B.; Lesma, G.; Palmisano, G.; Gabetta, B. J. Chem. Soc., Chem. Commun. 1981, 908-909. doi:10.1039/C39810000908

96. Sápi, J.; Szabó, L.; Baitz-Gács, E.; Kalaus, G.; Szántay, C. Tetrahedron 1988, 44, 4619-4629. doi:10.1016/S0040-4020(01)86164-0

97. Calabi, L.; Danieli, B.; Lesma, G.; Palmisano, G. J. Chem. Soc., Perkin Trans. 1 1982, 1371-1379. doi:10.1039/P19820001371

98. Kutney, J. P.; Chan, K. K.; Failli, A.; Fromson, J. M.; Gletsos, C.; Nelson, V. R. J. Am. Chem. Soc. 1968, 90, 3891-3893. doi:10.1021/ja01016a069

99. Laronze, P. J.-Y.; Laronze-Fontaine, J.; Lévy, J.; Le Men, J. Tetrahedron Lett. 1974, 15, 491-494. doi:10.1016/S0040-4039(01)82252-8

100. Kuehne, M. E.; Roland, D. M.; Hafter, R. J. Org. Chem. 1978, 43, 3705-3710. doi:10.1021/jo00413a015

101.Barsi, M.-C.; Das, B. C.; Fourrey, J.-L.; Sundaramoorthi, R. J. Chem. Soc., Chem. Commun. 1985, 88-89. doi:10.1039/C39850000088

102. Yoshida, K.; Nomura, S.; Ban, Y. Tetrahedron 1985, 41, 5495-5501. doi:10.1016/S0040-4020(01)91349-3

103. Kalaus, G.; Greiner, I.; Kajtár-Peredy, M.; Brlik, J.; Szabó, L.; Szántay, C. J. Org. Chem. 1993, 58, 1434-1442. doi:10.1021/jo00058a025

104.Kobayashi, S.; Peng, G.; Fukuyama, T. Tetrahedron Lett. 1999, 40, 1519-1522. doi:10.1016/S0040-4039(98)02667-7

105.Kuehne, M. E.; Podhorez, D. E. J. Org. Chem. 1985, 50, 924-929. doi:10.1021/jo00207a002

106. Pandey, G.; Kumara, P. C. Org. Lett. 2011, 13, 4672-4675. doi:10.1021/ol201892j

107. Jones, S. B.; Simmons, B.; Mastracchio, A.; MacMillan, D. W. C. Nature 2011, 475, 183-188. doi:10.1038/nature10232

108.Zhao, S.; Andrade, R. B. J. Am. Chem. Soc. 2013, 135, 13334-13337. doi:10.1021/ja408114u

109. Arisawa, M.; Terada, Y.; Nakagawa, M.; Nishida, A. Angew. Chem., Int. Ed. 2002, 41, 4732-4734. doi:10.1002/anie.200290031 


\section{License and Terms}

This is an Open Access article under the terms of the Creative Commons Attribution License

(http://creativecommons.org/licenses/by/2.0), which permits unrestricted use, distribution, and reproduction in any medium, provided the original work is properly cited.

The license is subject to the Beilstein Journal of Organic Chemistry terms and conditions:

(http://www.beilstein-journals.org/bjoc)

The definitive version of this article is the electronic one which can be found at:

doi:10.3762/bjoc. 10.261 